\section{CLIMATE CHANGE AND VIOLENT CONFLICT IN WEST AFRICA: ASSESSING THE EVIDENCE}

\section{KHEIRA TARIF*}

\section{Introduction}

There is growing evidence that the adverse effects of climate change increase both the risk and severity of violent conflict. The specific ways in which these effects impact violent conflict are, however, determined by local social, political and economic dynamics. ${ }^{1}$ While climate change is not the only cause of violence and conflict, it can have both direct and indirect consequences for local, national and even regional security.

West Africa is a hotspot of climate change and insecurity. ${ }^{2}$ Varied geographies, as well as social and political contexts, mean that changing temperatures, rainfall patterns and extreme weather events will have different impacts across the region. In order to build a better understanding of how climate change interacts with violent conflict in the region, this paper presents the findings of a systematic literature review of academic research on the Sahel and West Africa (see annex A), which covers Benin, Burkina Faso, Cabo Verde, Chad, Côte d'Ivoire, Gambia, Ghana, Guinea,Liberia, Mali, Mauritania, Niger, Nigeria, Senegal, Sierra Leone and Togo (see figure 1). The findings are structured along four established 'pathways': (a) worsening livelihood conditions; (b) increasing migration and changing pastoral mobility patterns; (c) tactical considerations by armed groups; and (d) elite exploitation of local grievances. $^{3}$

The review finds that worsening livelihood security and related responses to environmental degradation, changing migration patterns, predatory armed groups and elite behaviour all play a role in how the physical effects of climate change increase the risk of violent conflict in West Africa. Generally,

\footnotetext{
${ }^{1}$ Mobjörk, M., Krampe, F. and Tarif, K., 'Pathways of climate insecurity', SIPRI Policy Brief, Nov. 2020.

${ }^{2}$ United States Agency for International Development (USAID), 'Climate risk profile West Africa', 2018.

${ }^{3}$ Van Baalen, S. and Mobjörk, M., 'Climate change and violent conflict in East Africa: Integrating qualitative and quantitative research to probe the mechanisms', International Studies Review, vol. 20, no. 4 (Dec. 2018); and Nordqvist, P. and Krampe, F., 'Climate change and violent conflict: sparse evidence from South Asia and South East Asia', SIPRI Insights on Peace and Security no. 2018/4, Sep. 2018.
}

*This work was funded with support from the Swedish Ministry for Foreign Affairs as part of SIPRI's climate change and security project. The author would like to thank Anniek Barnhoorn for her significant contributions to earlier versions of this paper.

\section{SUMMARY}

- West Africa is widely cited as a hotspot of climate change and insecurity. This SIPRI Insights uses a systematic literature review of academic research to build a better understanding of the relationship between climate change and violent conflict in the region. Its findings are structured around four established 'pathways' of climate insecurity:

(a) worsening livelihood conditions; (b) increasing migration and changing pastoral mobility patterns; (c) tactical considerations by armed groups; and (d) elite exploitation of local grievances.

The literature review highlights a number of important variables in the relationship between climate change and violent conflict in West Africa: maladaptation to livelihood insecurity; migration away from climateexposed areas; escalating farmer-herder conflicts; and sometimes weak, sometimes divisive, sometimes exploitative governance. Despite these findings, the literature review reveals current research and policy discussions on climate change and violent conflict in West Africa are informed by a very limited amount of academic research. 


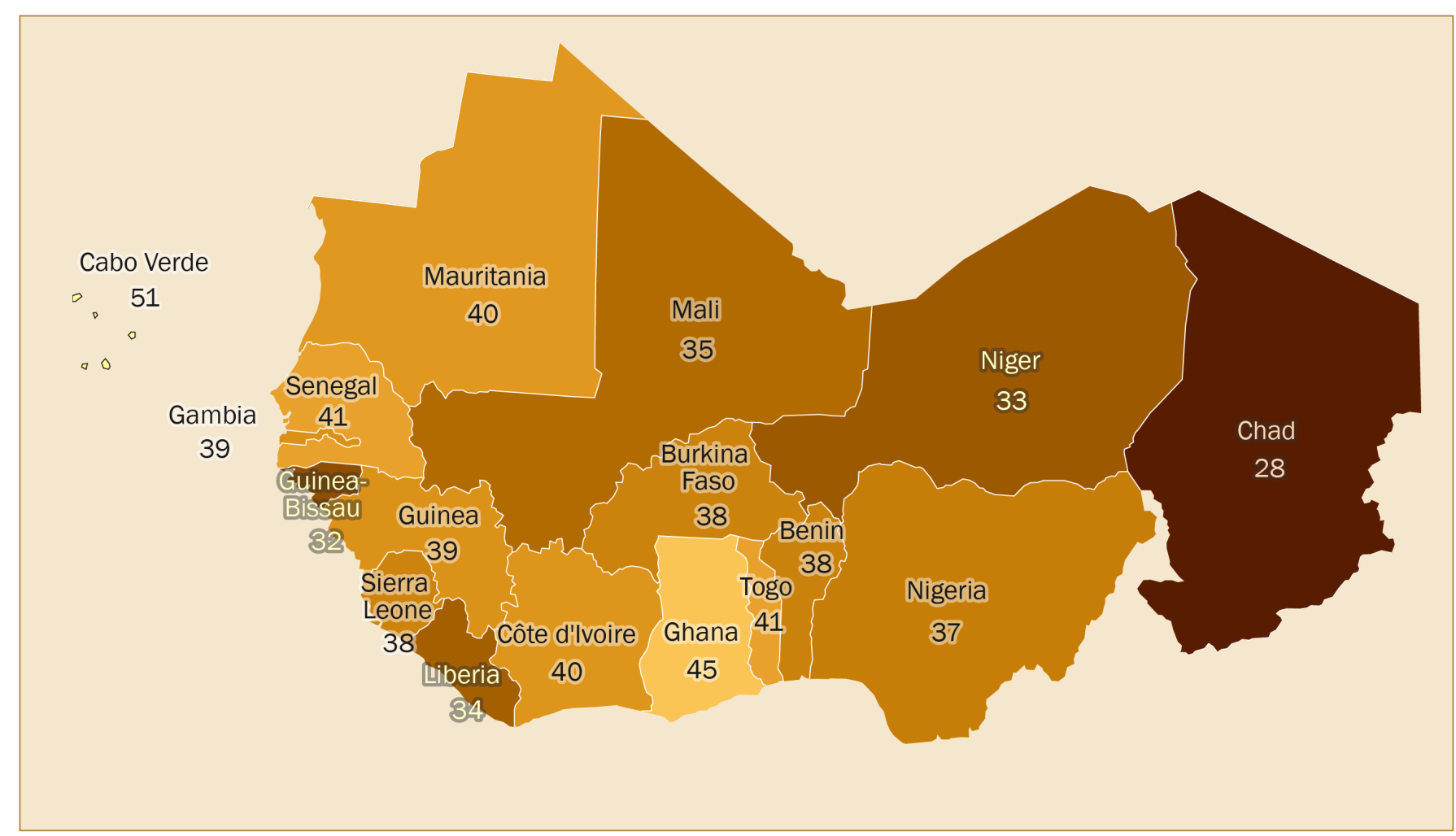

Figure 1. Map of United Nations Office for West Africa and the Sahel (UNOWAS) member states with ND-GAIN Country Index scores

Note: The ND-GAIN Country Index uses climate vulnerability and adaptation readiness indicators to develop a score from 1 (most vulnerable) to 100 (least vulnerable).

Sources: UNOWAS <https://unowas.unmissions.org/map> and ND-GAIN <https://gain.nd.edu/our-work/country-index/>.

there is indication of considerable overlap with pathways identified in other regions, including East Africa and South and South East Asia, although some findings suggest distinct dynamics in West Africa. The choices that individuals and communities make in adapting their livelihoods to the effects of climate change can increase the risk of violent conflict, while changing migration can accentuate conflict risks in less climate-exposed areas. Finally, the literature sample emphasizes the fundamental role of sometimes weak, sometimes divisive, sometimes exploitative governance in accentuating the conflict risks associated with climate change in West Africa.

While the review provides new insights into climate change and violent conflict in West Africa, the literature sample is relatively small and limited in scope, particularly considering the extensive coverage of the Sahel and West Africa in related policy discussions (see table A.1). The sample size is unsurprising, given that research on climate change and conflict generally leans towards relatively accessible regions. ${ }^{4}$ However, even within existing research, much of the region is neglected: the literature identified in this study focuses on just eight countries/regions (Burkina Faso, Côte d'Ivoire, Ghana, the Lake Chad Basin, Mali, Niger, the Niger River Basin and Nigeria-with Nigeria accounting for 30 per cent of case studies). The limited scope makes it difficult to draw firm conclusions on the relationship between

\footnotetext{
${ }^{4}$ Adams, C. et al., 'Sampling bias in climate-conflict research', Nature Climate Change, vol. 8, no. 3 (Mar. 2018).
} 
climate change and violent conflict across the whole region, and highlights the urgent need for more rigorous research across West Africa.

Following this introduction, the paper provides a brief background to the West African region (section II), proceeds to outline key findings from the literature review (section III) and concludes with their implications for future research and policymaking (section IV).

\section{Climate change, vulnerability and insecurity in West Africa}

\section{Climate change in West Africa}

Unprecedented changes in temperatures and precipitation are projected by the late 2030s and early 2040s in both the Sahel and tropical West Africa. ${ }^{5}$ Temperatures are expected to rise $3-6^{\circ} \mathrm{C}$ above late 20th century levels in the intermediate and worst-case emissions scenarios. ${ }^{6}$ In the Sahel, annual precipitation decreased throughout the 1900 s, leading to recurrent extreme droughts that had severe consequences for local ecosystems and communities. While future precipitation in the western Sahel is expected to decrease overall, more frequent storms and extreme rainfall in other parts could increase the risk of floods. ${ }^{7}$ Rising temperatures are expected to increase the

Rising temperatures are expected to increase the frequency and intensity ofdroughts in West Africa frequency and intensity of droughts, and to affect the West African monsoon season. ${ }^{8}$ In agricultural regions between the Sahel and the coastline, higher temperatures, increased evaporation and decreasing precipitation are projected to accentuate the risk of water stress, particularly in the dry seasons. ${ }^{9}$ From Senegal to Nigeria, rising sea levels will affect densely populated coastal regions vulnerable to waterborne diseases, heavy rainfall, floods and coastal erosion. ${ }^{10}$

\section{Climate vulnerability and governance}

The physical effects of climate change interact with existing social, economic and political vulnerabilities to increase the risk of violent conflict. Governance is a critical variable in climate vulnerability, as it can create or accentuate inequalities that worsen the effects of climate change on specific groups.

High reliance on agriculture is an important feature of climate vulnerability in West Africa. Agriculture, mainly informal and subsistence farm-

\footnotetext{
${ }^{5}$ Niang, I. et al., 'Africa', eds P. Dube and N. Leary, Climate Change 2014: Impacts, Adaptation, and Vulnerability. Part B:Regional A spects. Contribution of Working Group II to the Fifth Assessment Report of the Intergovernmental Panel on Climate Change (Cambridge University Press, 2014); and United Nations, 'UN support plan for the Sahel', 2018.

${ }^{6}$ Niang, I. et al. (note 5).

${ }^{7}$ Doblas-Reyes, F. J. et al., 'Linking global to regional climate change', eds V. Masson-Delmotte and P. Zhai, Climate Change 2021: The Physical Science Basis. Contribution of Working Group I to the Sixth Assessment Report of the Intergovernmental Panel on Climate Change (Cambridge University Press, 2021).

${ }^{8}$ Douville, H. K. et al., 'Water cycle changes', eds V. Masson-Delmotte and P. Zhai, Climate Change 2021: The Physical Science Basis. Contribution of Working Group I to the Sixth Assessment Report of the Intergovernmental Panel on Climate Change (Cambridge University Press, 2021).

${ }^{9}$ Douville, H. K. et al. (note 8).

${ }^{10}$ USAID (note 2).
} 
ing, makes up approximately 42.7 per cent of total regional employment. ${ }^{11}$ Livestock are a cornerstone of the regional food economy, contributing as much as 25 per cent of the total combined GDP of Burkina Faso, Mali and Niger. ${ }^{12}$ Agricultural sector governance also informs climate vulnerability. Population growth and an expanding commercial agricultural sector alter land use and land cover, while more intensive use of natural resources can exacerbate environmental degradation and water availability. ${ }^{13}$ This increases exposure to the negative effects of climate change, including rising temperatures and more erratic rainfall, on water resources and crop and livestock health.

Climate change also affects the sustainability and productivity of traditionally women-led activities and, due to the extra time spent collecting water and firewood, can increase the domestic workload of women and girls. ${ }^{14}$ Gender disparities in education, mobility, land and asset ownership and access to financial resources affect the livelihood security of women and their households. ${ }^{15}$ For example, although women make up approximately 43 per cent of the agricultural labour force across Burkina Faso, Cabo Verde, Côte d'Ivoire, Gambia, Guinea, Mali and Senegal, only 8 per cent of agricultural landowners are women. ${ }^{16}$

\section{Insecurity and humanitarian crises}

Climate vulnerability is also informed by the volatile security situation in some parts of West Africa, with insecurity and armed conflict affecting local and national capacities to mitigate and adapt to the effects of climate change. ${ }^{17}$

Multiple armed groups are active in some zones. In the Sahel this includes the Islamic State in the Greater Sahara (ISGS) and Jama'at Nasr al-Islam wal Muslimin (JNIM); while in the Lake Chad region Boko Haram and the Islamic State in West Africa Province (ISWAP) have a significant presence. As a consequence, regional and international counterinsurgency operations

\footnotetext{
${ }^{11}$ African Development Bank Group, 'West Africa economic outlook 2020: Coping with the COVID-19 pandemic', 2020.

${ }^{12}$ Leonhardt, M., 'Regional Policies and Response to Manage Pastoral Movements within the ECOWAS Region', International Organization for Migration (IOM) and Economic Community of West African States (ECOWAS), 2019.

${ }^{13}$ United Nations Department of Economic and Social Affairs (DESA), 'Graphs/profiles. World population prospects 2019', [n.d.]; and United States Geological Survey (USGS), USAID and Permanent Interstate Committee for Drought Control in the Sahel (CILSS), 'West Africa land use land cover time series', Feb. 2017

${ }^{14}$ McOmber, C., 'Women and climate change in the Sahel', West African Papers no. 27 (Sahel and West Africa Club, OECD, Mar. 2020).

${ }^{15}$ Walther, O. J., 'Femmes et conflits en Afrique de l'Ouest' [Women and Conflict in West Africa], West African Papers no. 28 (Sahel and West Africa Club, OECD, Mar. 2020); and Mbaye, A.A. and Gueye, F. 'Labor markets and jobs in West Africa', Working Paper Series no. 297 (African Development Bank Group, June 2018).

${ }^{16}$ Bouchama, N. et al., 'Gender inequality in West African social institutions', West African Papers no. 13 (Sahel and West Africa Club, OECD, Mar. 2018); and Allen, T., Herrings, P, and Heo, L., 'Agriculture, food and jobs in West Africa', West African Papers no. 14 (Sahel and West Africa Club, OECD, Apr. 2018).

${ }^{17}$ Moran, A. et al., 'The intersection of global fragility and climate risks' (USAID: Washington, DC, Sep. 2018).
} 
have proliferated, accompanied by reports of state violence against civilians. ${ }^{18}$

Community defence groups have also mobilized in response to insecurity, leading to a rise in violent inter-communal attacks and forced displacement in Burkina Faso's Centre-Nord and Soum, Mali's central Mopti, Niger's northern Tillaberi region, and Nigeria's North West zone. ${ }^{19}$ In Nigeria's Middle Belt, conflicts between farmers and herders have escalated into planned community attacks that sometimes surpass the lethality of Boko Haram. ${ }^{20}$

Parts of West Africa face complex humanitarian emergencies linked to violence, internal displacement, poverty and food insecurity. The number of people in need of assistance in the Sahel and Lake Chad more than doubled between 2019 and 2021, while the number of internally displaced persons (IDPs) registered in West Africa increased from under 2 million in 2014 to more than 7 million in 2021; including over 3 million in Nigeria alone. ${ }^{21}$

Climate change, disasters and violent conflict have a substantial impact on women and girls. For example, in the Lake Chad region of Chad, women and girls face sexual, physical and psychological violence, as well as structural disadvantages due to restricted access to land ownership, education and justice systems. ${ }^{22}$

\section{Pathways of climate insecurity}

The effects of climate change undermine livelihood security, food security, physical safety and health. ${ }^{23}$ Research shows that as well as the challenges climate change poses to human security, it can increase the risk of violent conflict: collective violence driven by social, political and/or economic motives.

This section outlines the key findings of a systematic review of academic literature on climate change and violent conflict in West Africa. Findings are organized along four pathways of climate insecurity, which have been found to highlight the broad processes from climate change to violent conflict: (a) worsening livelihood conditions; (b) increasing migration and changing pastoral mobility patterns; (c) tactical considerations by armed groups;

\footnotetext{
${ }^{18}$ Nsaibia, H., 'State atrocities in the Sahel: The impetus for counterinsurgency results is fueling government attacks on civilians', Armed Conflict Location and Event Data Project (ACLED), 20 May 2020.

${ }^{19}$ International Crisis Group (ICG), 'Reversing Central Mali's descent into communal violence', Africa Report no. 293, 9 Nov. 2020; and ICG, 'Murder in Tillabery: Calming Niger's emerging communal crisis', Africa Briefing no. 172, 28 May 2021; ICG, 'Burkina Faso: Stopping the spiral of violence', Africa Report no. 287, 24 Feb. 2020; and ICG, 'Violence in Nigeria's north west: Rolling back the mayhem', Africa Report no. 288, 18 May 2020.

${ }^{20}$ ICG, 'Herders against farmers: Nigeria's expanding deadly conflict', Africa Report no. 252, 19 Sep. 2017; ICG, 'Stopping Nigeria's spiralling farmer-herder violence', Africa Report no. 262, 26 July 2018

${ }^{21}$ United Nations Office for the Coordination of Humanitarian Affairs, 'Humanitarian needs and requirements overview: Sahel crisis', Apr. 2021; United Nations High Commissioner for Refugees, 'Operational data portal: Regional bureau for West and Central Africa', [n.d.].

${ }^{22}$ Le Masson, V. et al., 'How violence against women and girls undermines resilience to climate risks in Chad', Disasters, vol. 43, no. S3 (Apr. 2019).

${ }^{23}$ Mobjörk, M. et al., Climate-related Security Risks: Towards an Integrated Approach (SIPRI: Stockholm, Oct. 2016).
} 
and (d) elite exploitation of local grievances. ${ }^{24}$ These pathways identify when and under what circumstances climate change and violent conflict interact. They support analyses of the various actors, types of agency, local conditions and structures that increase the risk of violent conflict in climateexposed regions. Moreover, by directing attention to relevant processes and intervening factors, the pathways can support the identification of entry points for conflict prevention and peacebuilding. ${ }^{25}$

\section{Worsening livelihood conditions}

The adverse effects of climate change can increase the risk of violent conflict between groups that earn their livelihoods in climate-sensitive agriculture, pastoralism and fishery. Worsening livelihood conditions feed social, economic and political grievances by accentuating the marginalization of affected groups. In the absence of alternative livelihoods, there is greater risk of people using violence to protect or access natural resources. ${ }^{26}$

The literature sample on climate change, worsening livelihood conditions and violent conflict in West Africa highlights that weak local capacity in adapting livelihood strategies to climate change can increase the risk of water conflict; adaptation efforts may have negative outcomes leading to increased risk of violent competition over natural resources; and the combined effects of climate change and violent conflict can alter men's and women's livelihood security in different ways.

\section{Inflexible livelihoods accentuate local conflict risk}

The effects of climate change on temperatures and rainfall impact groups that rely primarily or entirely on natural resources such as freshwater,

Weak adaption capacities and limited alternative income-generating opportunities increase the risk of climate change fostering conflicts crops and pastures. The extent to which climate change leads to livelihood deterioration also depends on an individual's capacity to adapt, for example by developing new income sources. Where adaptation capacities are weak, or alternative income-generating opportunities are limited, there is greater risk of climate change effects fostering local resource conflicts.

In the Lake Chad region there is a higher risk of conflict around water access and use in places where water is critical to sustaining livelihoods and, as such, livelihoods are more vulnerable and less flexible. ${ }^{27}$ However, different groups experience vulnerability to water scarcity in different ways: pastoralists are most vulnerable in terms of water variability, livelihood strategies and social and political networks; farmers most vulnerable in terms of water conflicts; and fishers most vulnerable in terms of climate variability, water resources and low levels of education. ${ }^{28}$

\footnotetext{
${ }^{24}$ Van Baalen and Mobjörk (note 3); and Nordqvist and Krampe (note 3).

${ }^{25}$ Mobjörk, Krampe and Tarif (note 1).

${ }^{26}$ Van Baalen and Mobjörk (note 3).

27 Okpara, U. T. et al., 'Conflicts about water in Lake Chad: Are environmental, vulnerability and security issues linked?', Progress in Development Studies, vol. 15, no. 4 (Oct. 2015); and Okpara, U. T., Stringer, L. C. and Dougill, A. J., 'Lake drying and livelihood dynamics in Lake Chad: Unravelling the mechanisms, contexts and responses', Ambio, vol. 45 (Nov. 2016).

${ }^{28}$ Okpara, U. T., Stringer, L. C. and Dougill, A. J., 'Using a novel climate-water conflict vulnerability index to capture double exposures in Lake Chad', Regional Environmental Change, vol. 17 (Feb. 2017).
} 


\section{Responses to environmental degradation increase competition}

Climate change can accentuate environmental degradation and lead natural resource users to adapt by seeking alternative livelihood strategies or income sources. In West Africa, maladaptation (i.e. adaptation that has negative outcomes) can increase the risk of violent conflict. This is consistent with broader findings on the potential negative consequences of adaptation. ${ }^{29}$

Diversifying economic activities can lead to greater reliance on specific natural resources. In northern Burkina Faso, the effects of drought diminished pasture and water resources, leading livestock herders to rely less on migration and more on crop cultivation. ${ }^{30}$ In eastern Niger, farming communities diversified their livelihoods by purchasing livestock, while pastoralists sought to offset the effects of drought by engaging in farming. ${ }^{31}$ In both countries, increased overlap between livelihood activities intensified the use of key natural resources, thereby fostering competition.

Changing livelihood strategies can also mean migrating to comparatively fertile areas, with large-scale migration potentially contributing to a concentration of resource users and intensification of resource use. Competition over natural resources risks provoking conflict between farmers and herders, particularly when competition takes place in a broader context of changing land use. In Niger, the concentration of farmers and herders in pastoral and cultivation zones is accentuated by the expansion of farmland around protected areas. In response to growing competition over natural resources, herders seek to avoid confrontation with farmers by moving their livestock at night. They also carry small arms, increasing the risk of deadly violence. ${ }^{32}$

\section{Gendered impacts of worsening livelihood conditions}

Men and women in West Africa have differing customary roles within agricultural and pastoral livelihoods. In Nigeria's farming communities, women traditionally provide support to male relatives during planting, harvesting and crop processing; in pastoral communities, women process dairy milk and grow seasonal crops while men manage cattle herding. ${ }^{33}$ In both situations, women's livelihood strategies are generally defined by their male family members; as such, women often have less agency in defining adaptation strategies.

These customary roles can be altered when livelihood strategies are adapted to changing resource availability. In southern Burkina Faso male pastoralists increasingly diversify income using subsistence farming and fodder cultivation, with women and children assuming herd management

\footnotetext{
${ }^{29}$ Swatuk, L. A. et al., 'The "boomerang effect”: Insights for improved climate action', Climate and Development, vol. 13 (Feb. 2020); Dabelko, G. D. et al., Backdraft: The Conflict Potential of Climate Change Adaptation and Mitigation (Woodrow Wilson International Center for Scholars: Washington, DC, 2013); and Schipper, E. L. F., 'Maladaptation: When adaptation to climate change goes very wrong', One Earth, vol. 3, no. 4 (Oct. 2020).

${ }^{30}$ Traore, S. and Owiyo, T., 'Dirty droughts causing loss and damage in Northern Burkina Faso', International Journal of Global Warming, vol. 5, no. 4 (2013).

${ }^{31}$ Thébaud, B. and Batterbury, S., 'Sahel pastoralists: Opportunism, struggle, conflict and negotiation. A case study from eastern Niger', Global Environmental Change, vol. 11 (2001).

${ }^{32}$ Snorek, J., Renaud, F. G. and Kloos, J., 'Divergent adaptation to climate variability: A case study of pastoral and agricultural societies in Niger', Global Environmental Change, vol. 29 (Nov. 2014).

${ }^{33}$ Akinyemi, T. E. and Olaniyan, A., 'Nigeria: Climate war. Migratory adaptation and farmerherder conflicts', Conflict Studies Quarterly, vol. 21 (Oct. 2017).
} 
responsibilities that were previously carried out by men. ${ }^{34}$ In the dry season, young men herd cattle to water points during the day; in the rainy season, men take the cattle out at night, while women and children manage small ruminants grazing during the day. ${ }^{35}$ Although these adaptation strategies can increase the workload on women and girls, they potentially give them a larger role in income generation and decision-making around livelihood strategies.

\section{Entry points for addressing worsening livelihood conditions and conflict}

Local adaptation capacities and maladaptation are important variables in the relationship between climate change and violent conflict in West Africa. Livelihoods may be less resilient if they are inherently tied to climate-sensitive natural resources. In addition to the uptake of alternative livelihood strategies that potentially accentuate local resource competition, maladaptation can imply seeking alternative incomes in illegal activities (e.g. cattle rustling, kidnapping and trafficking) that benefit armed groups and criminal organizations. ${ }^{36}$ These findings suggest that strengthening livelihood resilience and facilitating sustainable livelihood adaptation are two entry points that can help prevent climate change from negatively affecting livelihood conditions and in turn contributing to violent conflict in West Africa.

\section{Increasing migration and changing pastoral mobility patterins}

Climate change can increase the incidence of extreme weather and disasters, jeopardizing livelihoods or even survival. While sudden disasters can lead to displacement, the effects of gradual climate change on migration are more diffuse and reminiscent of economic migration-that is, movement towards better income opportunities and urban migration. ${ }^{37}$ Migration, therefore, functions as an adaptation strategy for climate-affected groups.

Group-specific vulnerabilities inform when and how migration is used as an adaptation strategy in West Africa. The literature sample focuses on farmer-herder conflicts, particularly in Nigeria's Middle Belt region, emphasizing that changing pastoral mobility patterns play a key role in the relationship between climate change and violent conflict. Exploitative governance of the effects of climate change, and poor governance of the resulting increases in migration, also accentuate the risk of violent conflict.

\section{Differing vulnerabilities affect climate-related migration and conflict}

Local vulnerabilities and adaptation capacities inform how climate change affects livelihood deterioration. Migration can support the development of new income-generating activities or more resilient livelihood strategies,

\footnotetext{
${ }^{34}$ Nébié, E. K. I., West, C. T. and Crane, T. A., “"Where’s the map?”: Integrating ethnography with maps to understand the complementarity between pastoral mobility and border formation', Journal of Political Ecology, vol. 27, no. 1 (Jan. 2020).

35 Nébié, West and Crane (note 34$)$.

${ }^{36}$ Owonikoko, S. B. and Momodu, J. A., 'Environmental degradation, livelihood, and the stability of Chad Basin Region', Small Wars \& Insurgencies, vol. 31, no. 6 (Aug. 2020).

${ }^{37}$ Clement, V. et al., Groundswell Part 2: Acting on Internal Climate Migration (World Bank: Washington, DC, Sep. 2021); and Barnett, J. and Adger, W. N., 'Mobile worlds: choice at the intersection of demographic and environmental change', Annual Review of Environment and Resources, vol. 43, no. 1(Oct. 2018).
} 
while migration decisions are also informed by a group's specific vulnerabilities and mobility options.

Livelihoods that are closely tied to climate-sensitive natural resources are both less resilient to the effects of climate change and potentially more vulnerable to conflict- and climate-related displacement. ${ }^{38}$ In northeastern Nigeria, for example, communities with a high dependence on natural resources are more vulnerable to conflict and more likely to experience displacement than groups with alternative income sources. ${ }^{39}$

Large-scale displacement can lead to a concentration of resource users and intensified resource use. The arrival of conflict-displaced people in fertile areas of the Lake Chad Basin, for instance, has led to increased crowding and pressure on water resources. This heightens competition and increases the risk of conflict, while over-use of local natural resources accentuates exposure to the effects of climate change. ${ }^{40}$

Migrant pastoralists are a particularly vulnerable group when it comes to the effects of climate change and environmental degradation, as they need freshwater and pasture access throughout the year. They often lack formal claims to natural resources and so must negotiate access with local communities. Migration can also expose them to violent conflicts in the region. The Mbororo, seasonal migrant pastoralists of the larger Fulani ethnic group, who travel to the Lake Chad Basin, offer one example. The Mbororo are marginalized in terms of their access to land and water resources, in part because they do not lay any claim to specific lands in the region. Having previously relied on local water-sharing agreements, recent shifts to modern large-scale water management have jeopardized their access to critical water points. With the combined effects of climate change and overexploited water resources affecting the availability of freshwater in Lake Chad, the Mbororo have become increasingly involved in escalating inter-communal conflicts. ${ }^{41}$

\section{Changing pastoral livelihoods, changing pastoral mobility patterns}

Pastoralists use a range of migration strategies to cope with seasonal resource availability: long-distance transhumant pastoralism, short-distance or semisedentary pastoralism, and job-seeking migration. ${ }^{42}$ However, the effects of climate change-rising temperatures, evapotranspiration, changing seasonal rainfall patterns and diseases-affect the health of water, pastures and livestock.

Research in the literature sample reflects growing concern regarding the frequency and severity of conflicts between farmers and migrant herders over natural resources, particularly in Nigeria. Desertification, aridification

\footnotetext{
${ }^{38}$ Kamta, F. N., Schilling, J. and Scheffran, J., 'Insecurity, resource scarcity, and migration to camps of internally displaced persons in northeast Nigeria', Sustainability, vol.12, no. 17 (Aug. 2020).

${ }^{39}$ Kamta, Schilling and Scheffran (note 38).

40 Nagabhatla, N. and Brahmbhatt, R., 'Geospatial assessment of water-migration scenarios in the context of Sustainable Development Goals (SDGs) 6,11, and 16', Remote Sensing, vol.12, no. 9 (Jan. 2020); and Owonikoko and Momodu (note 36).

${ }^{41}$ Nagabhatla, N. et al., 'Water, conflicts and migration and the role of regional diplomacy: Lake Chad, Congo Basin, and the Mbororo pastoralist', Environmental Science \& Policy, vol. 122 (Aug. 2021).

${ }^{42}$ Bukari, K. N. et al., 'Diversity and multiple drivers of pastoral Fulani migration to Ghana', Nomadic Peoples, vol. 24, no. 1 (Mar. 2020).
} 
and resulting water stress negatively impact grazing resources in northern Nigeria, with some research finding that herders are adapting by migrating north-south at different times of the year. This increases the risk of livestock damaging seasonal agriculture and conflicts ensuing between farmers and herders. ${ }^{43}$ Other studies find that a growing number of herders are migrating southwards and crowding into certain regions, thereby creating more competition and conflict with farmers. ${ }^{4}$

One study finds that northern Nigeria is more vulnerable to climate change but less vulnerable to farmer-herder conflicts, while adjacent regions in the northeast and northwest, despite being less vulnerable to climate change, are most vulnerable to farmer-herder conflicts. ${ }^{45}$ The authors conclude that farmer-herder conflict is least likely to occur in areas where

Changing migration patterns may mean higher conflict risks where the effects of climate change are less significant

the effects of climate change are most acute, and most likely to occur in areas where its effects are less acute. These findings support the view that livestock herders in Nigeria are moving into regions less impacted by climate change but increasingly impacted by resource conflicts. Changing migration patterns may actually mean the conflict risks associated with climate change are highest in regions where the effects of climate change are less significant, which fits with research findings indicating that climate change, migration and conflict can intersect in situations of resource abundance as well as scarcity. ${ }^{46}$

\section{Governance mediates climate change, migration and conflict relationships}

Research on climate change and violent conflict in East Africa found that migration can escalate resource conflicts when different groups, lacking common conflict-resolution mechanisms, are forced together. ${ }^{47}$ While the literature on West Africa does to an extent acknowledge the role of disputeresolution mechanisms in preventing violent escalation, greater emphasis is placed on poor governance accentuating the risk of farmer-herder conflict. This includes government failures to address the adverse effects of climate change, tackle small arms proliferation and effectively manage farmerherder conflicts. ${ }^{48}$ An expanding agriculture sector, driven by population growth and commercial farming, also squeezes herders' access to natural resources. ${ }^{49}$

Governance of ethnic diversity is another factor, with ethnic and/or religious tensions potentially contributing to conflict escalation between

\footnotetext{
${ }^{43}$ Igwe, D. O., 'Climate variation-induced migration, land conflicts, and security situation in Nigeria', Age of Human Rights Journal, no. 14 (June 2020); and Akinyemi and Olaniyan (note 33).

${ }^{44}$ Lenshie, N. E. et al., 'Desertification, migration, and herder-farmer conflicts in Nigeria: rethinking the ungoverned spaces thesis', Small Wars \& Insurgencies (30 Aug. 2020); Okoli, A. C. and Ogayi, C. O., 'Herdsmen militancy and humanitarian crisis in Nigeria: a theoretical briefing', African Security Review, vol. 27, no. 2 (Apr. 2018); and Olaniyan A. and Okeke-Uzodike, U., 'Desperate guests, unwilling hosts: climate change-induced migration and farmer-herder conflicts in southwestern Nigeria', Conflict Studies Quarterly, no. 10 (Jan. 2015).

${ }^{45} \mathrm{Madu}$, I. A. and Nwankwo, C. F., 'Spatial pattern of climate change and farmer-herder conflict vulnerabilities in Nigeria', GeoJournal (20 May 2020).

${ }^{46}$ Freeman, L., 'Environmental change, migration, and conflict in Africa: a critical examination of the interconnections', Journal of Environment \& Development, vol. 26, no. 4 (Dec. 2017).

${ }^{47}$ Van Baalen and Mobjörk (note 3).

${ }^{48}$ Lenshie et al. (note 44$)$.

${ }^{49}$ Igwe (note 43); and Okoli and Ogayi (note 44).
} 
migrant herders and farmers in West Africa. ${ }^{50}$ The literature sample extensively covers conflicts between ethnic Fulani herders and other groups, with just one article dealing with intra-group tensions between settled and migratory Fulani herders in Nigeria. ${ }^{51}$ Despite a consensus that Fulani herders are changing their migration patterns in response to the effects of climate change, research sometimes describes them as armed actors, even militias. This framing is used to advocate improved local security and policing as a response to changing herder migration patterns in Nigeria. ${ }^{22}$ Such singling out of a particular group as a security threat can have broader consequences for peace and conflict. In the 1970s and 1980s, severe droughts had devastating impacts on the livelihoods of Tuareg pastoralists in northern Mali. In this context, harmful governance-sedentarization policies, local corruption, and repression and marginalization of pastoralist Tuaregs-contributed to many young Tuaregs migrating to Algeria and Libya, where they were exposed to revolutionary political trends and gained military experience participating in regional conflicts. These migrants later became instrumental in the 1990-96 Tuareg rebellion against the Malian Government. ${ }^{53}$ This example illustrates how climate change, livelihood deterioration and migration interact with governance of ethnic diversity to increase the risk of violent conflict.

\section{Entry points for addressing migration, mobility and conflict}

Local vulnerabilities, changing pastoral mobility and governance inform the relationship between climate change, migration and violent conflict in West Africa. Groups dependent on climate-sensitive natural resources are at highest risk of climate change, violent conflict and displacement. Responses to climate change and violent conflict can result in resource use being concentrated, thereby heightening the risk of resource competition. Changing pastoral mobility patterns also exacerbate the risk of farmerherder conflicts, particularly when governance systems create inequalities between livelihood groups. Increasing migration and changing pastoral mobility patterns mean that regions less impacted by the effects of climate change may actually face greater conflict risks than highly climate-exposed regions. Understanding this link between climate change, migration and violent conflict in West Africa can help in identifying conflict hotspots and preventing escalation.

\footnotetext{
${ }^{50} \mathrm{Madu}$ and Nwankwo (note 45); Okoli and Ogayi (note 44); Olaniyan and Okeke-Uzodike (note 44); and Olaniyan, A., Francis, M. and Okeke-Uzodike, U., 'The cattle are "Ghanaians" but the herders are strangers: farmer-herder conflicts, expulsion policy, and pastoralist question in Agogo, Ghana', African Studies Quarterly, vol. 15, no. 2 (2015).

${ }^{51}$ Robert, É., 'Les zones pastorales comme solution aux conflits agriculteurs / pasteurs au Burkina Faso : l'exemple de la zone pastorale de la Doubégué' ['Pastoral zones as a solution to farmer / pastoralist conflicts in Burkina Faso: the example of the pastoral zone of Doubégué'], Cahiers d'Outre-Mer, vol. 63, no. 249 (Jan. 2010); Akinyemi and Olaniyan (note 33); Bukari et al. (note 42); Freeman (note 46); Igwe (note 43); Lenshie et al. (note 44); Madu and Nwankwo (note 45); Nagabhatla et al. (note 41); Okoli and Ogayi (note 44); Snorek, Renaud and Kloos (note 32); and Olaniyan and Okeke-Uzodike (note 44).

52 Akinyemi and Olaniyan (note 33); Okoli and Ogayi (note 44); and Lenshie et al. (note 44).

${ }^{53}$ Benjaminsen, T. A., 'Does supply-induced scarcity drive violent conflicts in the African Sahel? The case of the Tuareg rebellion in northern Mali', Journal of Peace Research, vol. 45, no. 6 (Nov. 2008).
} 


\section{Tactical considerations by armed groups}

As well as increasing the risk of local conflicts, climate change can affect the dynamics of broader hostilities by altering natural, human and other resource availability, and providing new opportunities for armed groups. In East Africa and South and South East Asia, armed groups have used the impacts of extreme weather on livelihoods to boost recruitment. ${ }^{54}$ Moreover, in East Africa, armed groups have altered their behaviour in response to weather conditions, using wetter weather and thicker vegetation cover to mask their operations. ${ }^{55}$

There is comparatively limited reference in the literature sample to the relationship between climate change, the tactical considerations of armed groups and violent conflict in West Africa. There is evidence that short-term rainfall deficits in the Niger River Basin increase the risk of political violence by undermining livelihood and food security. ${ }^{56}$ Armed groups have capitalized on the effects of climate change on livelihoods to gain support and recruits, while military operations against armed groups in climate-exposed regions have sometimes accentuated livelihood insecurity and increased local vulnerability to climate change. In all cases, the research highlights the importance of governance: weak governance increases the risk of insecurity; harmful governance accentuates vulnerability; and non-state or informal governance can offer an alternative.

\section{Armed groups capitalize on environmental degradation and weak governance}

In the Lake Chad Basin, weak transboundary governance and worsening livelihood conditions linked to the lake's shrinking surface area mean illegal activities have long been used as alternative income sources. ${ }^{57}$ Armed groups have used the same confluence of factors to boost support and recruitment. Both Boko Haram and ISWAP have played on local political and economic grievances in the Lake Chad region, offering loans or salaries to gain support and recruits in communities exposed to climate change and environmental degradation. ${ }^{58}$ Boko Haram also uses cattle rustling and agents who sell stolen livestock in local markets, as well as kidnapping and trafficking in drugs, people and arms, to gain revenue. ${ }^{59}$

\section{Escalating farmer-herder conflicts in Nigeria}

The case of armed herder groups in Nigeria is distinct from previous findings on climate change, tactical considerations by armed groups and violent conflict in East Africa and South and South East Asia. Over the past decade, farmer-herder violence in Nigeria has escalated from small local clashes to organized militancy among migrant herders. These armed herders use increasingly sophisticated small arms to raid farming villages in Nigeria's

\footnotetext{
${ }^{54}$ Van Baalen and Mobjörk (note 3); and Nordqvist and Krampe (note 3).

${ }^{55}$ Van Baalen and Mobjörk (note 3).

${ }^{56}$ Landis, S. T. et al., 'Fording differences? Conditions mitigating water insecurity in the Niger River Basin', Political Geography, vol. 56 (Jan. 2017).

57 Owonikoko and Momodu (note 36).

${ }^{58}$ Varin, C., 'No opportunity lost: the ISWAP insurgency in the changing climate of Lake Chad Region',African Conflict and PeacebuildingReview, vol.10, no. 2 (2020); and Owonikoko and Momodu (note 36).

${ }^{59}$ Owonikoko and Momodu (note 36).
} 
Middle Belt region, leading to significant internal displacement, loss of local livelihoods, disrupted food production and food insecurity. Farming communities have responded by mobilizing self-defence groups, worsening the cycle of violent conflict.

Multiple factors have contributed to the escalation of local resource conflicts into violent intra-communal conflict in Nigeria. These include climate pressure on freshwater, pastures and livestock migration routes, as well as weak governance of land, natural resources and the livestock sector in rural areas. ${ }^{60}$ The effects of climate change in northern Nigeria, worsening livelihood conditions for migrant herders, changing pastoral mobility patterns towards the Middle Belt region, and weak governance of increasingly contested natural resources have in combination contributed to turning isolated local resource conflicts into broader intra-communal violence.

Military responses accentuate environmental degradation and vulnerability

Armed conflict contributes to worsening livelihood conditions for vulnerable groups and accentuates vulnerability to climate change. Military operations against armed groups in the Lake Chad region, for instance, have sometimes exacerbated livelihood insecurity and increased local livelihoods' vulnerability to the effects of climate change. Forced evacuations from islands in the lake, fish market closures and military-imposed restrictions on movement during counterinsurgency operations affect local communities' access to their sources of income. ${ }^{61}$ These decisions have displaced populations and affected some of the most vulnerable livelihood groups, for example reducing fishers' access to water and herders' access to pastures. ${ }^{62}$

\section{Climate change and informal governance during violent conflict}

In contrast to weak and harmful governance-which can accentuate the relationship between climate change, the tactical considerations of armed groups and violent conflict-strong informal governance can improve responses to disasters in conflict-affected regions. In Mali, armed groups' control over territory and relations with civilians, as well as the strength of informal local institutions, are found to improve the prospects for disaster risk reduction (DRR) programming. ${ }^{63}$ Diverse types of governance can, therefore, contribute to building local community resilience to climaterelated disasters and violent conflict.

\section{Entry points for addressing violent conflict in climate-exposed regions}

In West Africa, the effects of climate change in areas of weak governance have provided opportunities for armed groups to mobilize local support and new recruits. In Nigeria, the convergence of climate change, degraded pastoralist livelihoods, changing pastoral mobility patterns and weak government resource management is contributing to the escalation of local farmer-herder conflicts. Armed conflict and military operations can also

\footnotetext{
${ }^{60}$ Okoli and Ogayi (note 44).

${ }^{61}$ Varin (note 58).

62 Varin (note 58).

${ }^{63}$ Walch, C., 'Disaster risk reduction amidst armed conflict: Informal institutions, rebel groups, and wartime political orders', Disasters, vol. 42, no. S2 (Oct. 2018).
} 
be harmful for vulnerable natural resource-based livelihoods, potentially even reinforcing armed groups' anti-government narratives. These findings emphasize the role of local governance in shoring up community resilience to the effects of climate change and violent conflict. This includes informal governance, which can support humanitarian action operations in cases where the state is too weak or absent. In terms of hard security outcomes arising from the relationship between climate change, the tactical considerations of armed groups and violent conflict, findings on the critical role of good governance emphasize that hard security solutions alone cannot address the drivers of conflicts in West Africa.

\section{Elite exploitation of local grievances}

In East Africa and South and South East Asia, climate change is more likely to increase the risk of local conflicts than civil wars. ${ }^{64}$ If exploited by local or national elites, though, small-scale tensions can increase the risk of broader conflict. For example, in the aftermath of sudden disasters, local elites can amass power by controlling humanitarian aid distribution. ${ }^{65}$ In East Africa, political elites have incited farmer-herder violence in the run-up to national elections and taken advantage of the resulting ethnic tensions in their campaigns. ${ }^{66}$

In West Africa, it is not just a matter of elites exploiting local grievances related to climate change. The literature sample shows that governments create local grievances with weak and sometimes divisive governance choices that increase vulnerability to the effects of climate change and drive violent conflicts. Ineffective or iniquitous natural resource governance increases the risk of resource conflicts, which may then be politicized and exacerbated by elites. National governance can also impede effective responses to regional crises and increase the risk of intrastate conflict.

\section{Mismanagement and unequal distribution of natural resources}

When local institutions mismanage natural resources, resulting inequalities in resource users' access can increase the risk of conflict. In Mali's Inner Niger Delta, court records show that farmer-herder conflicts coalesced around two related issues: first, the expansion of agriculture into livestock corridors, and, second, the encroachment of rice farming onto livestock grazing pastures. ${ }^{67}$ There was little evidence that the incidence of farmer-herder land disputes increased in the aftermath of abnormally high precipitation levels, leading the authors of the study to find that local land conflicts were best explained by weak local governance and resource management. ${ }^{68}$

In Niger's Tahoua region, disputes over resource access and use are accentuated by the privatization of fields, pastures and lakes that were previously commons resources, and weak local governance. ${ }^{69}$ One study found a higher

\footnotetext{
${ }^{64}$ Van Baalen and Mobjörk (note 3); and Nordqvist and Krampe (note 3).

${ }^{65}$ Nordqvist and Krampe (note 3).

${ }^{66}$ Van Baalen and Mobjörk (note 3).

${ }^{67}$ Benjaminsen, T. A. et al., 'Does climate change drive land-use conflicts in the Sahel?', Journal of Peace Research, vol. 49, no.1 (Jan. 2012).

${ }^{68}$ Benjaminsen et al. (note 67).

${ }^{69}$ Snorek, J., Moser, L. and Renaud, F. G., 'The production of contested landscapes: Enclosing the pastoral commons in Niger', Journal of Rural Studies, vol. 51 (Apr. 2017).
} 
incidence of water conflict in a village where local authorities did not enforce pastoral land and water management rules, in contrast to the greater cooperation witnessed between farmers and herders in another village where authorities did enforce such rules. ${ }^{70}$ In the context of a changing climate and its impact on natural resource availability, good governance has a critical role to play in preventing conflicts and even promoting cooperation.

\section{Elite manipulation and exploitation oflocal conflicts}

Elite manipulation and exploitation accentuate the impacts of climate change on some groups more than others. The risk of resource conflict escalation in Burkina Faso, Côte d'Ivoire and Mali, for example, is higher when local disputes overlap with election periods or national political narratives around immigrants. ${ }^{71}$ Moreover, elite exploitation can cause local resource conflicts to escalate into broader conflicts between identities.

In Ghana, pressure on natural resources can lead local farmers to advocate that migrant Fulani herders be physically expelled and prohibited from re-entering the country. West African governments have sometimes deployed herder expulsion policies during economic hardship or in response

The risk of resource conflict escalation is higher in some areas when local disputes overlap with election periods or political narratives around immigrants to conflict between migrant herders and host communities.

Such policy choices are framed in ethnic and national language: for example, supporting the rights of indigenous Ghanaians over Fulani migrant 'strangers'. Herder expulsions can also be a politically expedient alternative to regulating or sedentarizing migrant herder groups-including herders employed by Ghanaian elites to manage their large cattle herds. ${ }^{72}$

\section{Intrastate conflict}

The effects of climate change can also impact state-level disputes, with weak transboundary governance increasing the risk of competition and insecurity. In the Lake Chad Basin, severe droughts in the 1980s led to several militarized conflicts over competing water claims, including Nigeria-Niger clashes over water diversion and access to the Komadugu-Yobe River, and Nigeria-Cameroon disputes over border demarcation claims. ${ }^{73}$ In 2007, violent clashes between Nigerian fishers and Cameroonian and Chadian gendarmes almost escalated into an international military confrontation between the three states. ${ }^{74}$ As well as increasing the risk of conflict over water resources in the Lake Chad region, weak transboundary water agreements affect state cooperation on other issues, including environmental degradation, migration and armed groups. ${ }^{75}$ These examples highlight how climate change and weak state governance can increase the risk of militarized international conflicts.

\footnotetext{
${ }^{70}$ Snorek, Moser and Renaud (note 69).

${ }^{71}$ Seter, H., Theisen, O. M. and Schilling, J., 'All about water and land? Resource-related conflicts in East and West Africa revisited', GeoJournal, vol. 83, no. 1 (Feb. 2018).

72 Olaniyan, Francis and Okeke-Uzodike (note 50).

73 Okpara et al. (note 27); and Owonikoko and Momodu (note 36).

74 Owonikoko and Momodu (note 36).

75 Owonikoko and Momodu (note 36 ).
} 


\section{Entry points for shoring up governance and policy responses}

Beyond the exploitation of local grievances by elites, the literature sample highlights the role of weak and divisive governance in both accentuating local vulnerabilities to the effects of climate change and increasing

Across all four pathways of climate insecurity in West Africa, governance is found to be critical

the risk of violent conflict. Inadequate natural resource management can lead to resource conflicts between farmers and herders. In addition, government responses to these conflicts can contribute to the marginalization of specific groups, such as Fulani herders. Weak transboundary governance fosters competition and insecurity, while low levels of international cooperation around key resources can exacerbate the risks of intrastate conflicts.

Across all four pathways of climate insecurity, governance is found to be critical when it comes to the conflict risks associated with climate change in West Africa. Addressing insecurity in climate-exposed regions requires that reinforcement of legitimate and inclusive governance mechanisms is prioritized.

\section{Implications for research and policymaking}

This systematic literature review reveals a number of important findings on climate change and violent conflict in West Africa. While it finds significant overlap with the pathways identified in previous studies on East Africa and South and South East Asia, it also points to complementary findings in each of the four pathways. ${ }^{76}$ Namely, that climate change and violent conflict intersect when (a) maladaptation accentuates local resource competition; (b) increasing migration, as an adaptation strategy, heightens resource competition in areas less impacted by climate change; (c) weak governance provides armed groups with new opportunities or leads to increased reliance on armed self-defence; and $(d)$ weak and sometimes divisive governance increases climate vulnerability, feeds local grievances and drives violent conflicts.

Along with these findings, two challenges for research and policymaking remain. First, though this paper identifies important findings from local case studies, the size and scope of the literature makes it difficult to draw firm conclusions on the relationship between climate change and violent conflict across West Africa. Despite the broad, high-level policy interest in this topic and region, this paper identified a relatively small sample of rigorous academic research. Moreover, even within existing research, much of the region is neglected; coastal regions are poorly represented in the literature sample, despite being projected to experience significant, if different, climate impacts. The lack of research on how local climate vulnerabilities may produce risks that manifest differently-or are labelled differently-in particular contexts, remains an important challenge for both research and policymaking.

The second challenge is the absence of long-term perspectives on future climate change and violent conflict. Only one research paper in the sample (looking at colonial Nigeria) considered the long-term effects of climate

\footnotetext{
${ }^{76}$ Van Baalen and Mobjörk (note 3); and Nordqvist and Krampe (note 3).
} 
change on environmental degradation and violent conflict. ${ }^{77}$ Furthermore, no study considered future trends in climate change and violent conflict. Without long-term perspectives on how climate change and violent conflict interact, there is no way of conceptualizing ways climate mitigation and adaptation programmes risk unintentionally creating new, or accentuating existing, conflict dynamics. As a result, policymakers are left without the evidence they need to promote climate- and conflict-sensitive development in West Africa.

More research is needed to better understand the relationship between climate change and violent conflict in West Africa, and in turn advance guidance for climate- and conflict-sensitive policymaking. There are three areas that are particularly important with regard to future research efforts: livelihood resilience and climate adaptation, the dynamics of changing migration patterns and changing risks and local governance mechanisms.

\section{Livelihood resilience and climate adaptation}

West African communities faced with the adverse effects of climate change and violent conflict are adapting their livelihoods to cope with increased insecurity. Further research should contribute to a better understanding of the factors underlying resilient livelihoods, as well as to policies and programming that support locally led climate adaptation efforts, reinforce livelihoods and reduce the risk of violent conflict. Future research must pay particular attention to the differentiated effects of climate change and violent conflict on men and women, boys and girls.

\section{The dynamics of changing migration patterns and changing risks}

Increasing migration and changing pastoral mobility patterns can transform climate impacts in one area of West Africa into conflict risks in neighbouring zones. Further research into how and where migration influences the relationship between climate change and violent conflict can contribute to strengthening regional conflict prediction and responses.

\section{Local governance mechanisms}

In West Africa, the effects of climate change in areas of weak governance have provided armed groups with opportunities to mobilize local support and new recruits. Divisive governance also accentuates local vulnerabilities to the effects of climate change and increases the risk of violent conflict. Local, even informal, governance can be critical in shoring up community resilience, both to the effects of climate change and to violent conflict. Better understanding and mapping of local mechanisms can be a first step to strengthening bottom-up governance and peacebuilding.

\footnotetext{
${ }^{77}$ Papaioannou, K. J., 'Climate shocks and conflict: evidence from colonial Nigeria’, Political Geography, vol. 50 (Jan. 2016).
} 


\section{Annex A. Methodology}

This paper conducted a systematic review of academic literature on climate change and violent conflict in West Africa, using a Boolean search string to identify peer-reviewed journal articles on climate change and violent conflict. ${ }^{a}$ This search combined climateand conflict-related keywords with West African countries and regions, and used operators (AND, OR, NOT, etc.) to identify relevant journal articles in a targeted search of online databases: $[\mathrm{AB}=$ (climat* OR "climat* change" OR "climat* variability" OR rainfall OR precipitation OR drought OR "water scarcity” OR "land degradation” OR weather OR disaster OR temperature OR warming OR "sea level rise" OR desertification OR famine OR erosion OR flood*) AND (conflict OR violence OR unrest OR jihad* OR armed OR insurgen* OR rebel* OR terror* OR violen* OR war OR protest*) AND ("west africa" OR sahel OR benin OR "burkina faso" OR chad OR "côte d'ivoire" OR "ivory coast" OR gambia OR ghana OR guinea OR liberia OR mali OR mauritania OR niger OR nigeria OR "cape verde" OR “cabo verde" OR senegal OR "sierra leone" OR togo)]

An initial search identified a sample of 382 English-language peer-reviewed articles in ProQuest and Web of Science, and 25 French-language articles in Cairn.info. A manual inspection of abstracts excluded articles that did not focus primarily on climate change or conflict, resulting in a sample of 52 English-language and 6 French-language articles. This sample was manually coded using a set of questions to examine explanations of the relationship between climate conditions and conflict; intervening variables in this relationship; the groups affected by climate change and conflict; and the circumstances under which climate change is found to be linked to conflict. Articles that did not focus on climate-related environmental change and conflict, qualitative articles that did not examine at least one West African country, and quantitative articles that did not predominantly focus on West Africa were excluded from the final sample.

The final sample consists of 30 articles (see table A.1), which is smaller than the literature sample for East Africa ( $\mathrm{N}=43)$, but greater than the literature sample for South and South East Asia ( $\mathrm{N}=21) .^{b}$ This paper's conclusions may not be generalizable to the whole of West Africa due to the small sample size, which points to the need for more academic research on the relationship between climate change and violent conflict in the region.

\footnotetext{
${ }^{a}$ Van Baalen, S. and Mobjörk, M., 'Climate change and violent conflict in East Africa: integrating qualitative and quantitative research to probe the mechanisms', International Studies Review, vol. 20, no. 4 (Dec. 2018).

$b^{b}$ Van Baalen and Mobjörk (note a); and Nordqvist, P. and Krampe, F., 'Climate change and violent conflict: Sparse evidence from South Asia and South East Asia', SIPRI Insights on Peace and Security, no. 2018/4, Sep. 2018.
} 
Table A.1. Full details of the literature sample

\begin{tabular}{|c|c|c|c|c|c|}
\hline Authors & Title & Publication & Area examined & Method & Pathway \\
\hline $\begin{array}{l}\text { Akinyemi and } \\
\text { Olaniyan (2017) }\end{array}$ & $\begin{array}{l}\text { Nigeria: Climate war. } \\
\text { Migratory adaptation and } \\
\text { farmer-herder conflicts }\end{array}$ & $\begin{array}{l}\text { Conflict Studies } \\
\text { Quarterly }\end{array}$ & Nigeria & Qualitative & $\begin{array}{l}\text { Migration and mobility } \\
\text { patterns }\end{array}$ \\
\hline $\begin{array}{l}\text { Benjaminsen } \\
(2008)\end{array}$ & $\begin{array}{l}\text { Does supply-induced } \\
\text { scarcity drive violent } \\
\text { conflicts in the African } \\
\text { Sahel? The case of the } \\
\text { Tuareg rebellion in } \\
\text { northern Mali }\end{array}$ & $\begin{array}{l}\text { Journal of Peace } \\
\text { Research }\end{array}$ & Mali & Qualitative & $\begin{array}{l}\text { Migration and } \\
\text { mobility patterns; elite } \\
\text { exploitation }\end{array}$ \\
\hline $\begin{array}{l}\text { Benjaminsen, } \\
\text { Alinon, Buhaug } \\
\text { and Buseth (2012) }\end{array}$ & $\begin{array}{l}\text { Does climate change drive } \\
\text { land-use conflicts in the } \\
\text { Sahel? }\end{array}$ & $\begin{array}{l}\text { Journal of Peace } \\
\text { Research }\end{array}$ & Mali & Mixed & Elite exploitation \\
\hline $\begin{array}{l}\text { Bukari, Bukari, } \\
\text { Sow and Scheffran } \\
(2020)\end{array}$ & $\begin{array}{l}\text { Diversity and multiple } \\
\text { drivers of pastoral Fulani } \\
\text { migration to Ghana }\end{array}$ & Nomadic Peoples & Ghana & Qualitative & $\begin{array}{l}\text { Migration and mobility } \\
\text { patterns }\end{array}$ \\
\hline $\begin{array}{l}\text { Busby, Smith, } \\
\text { White and Strange } \\
\text { (2013) }\end{array}$ & $\begin{array}{l}\text { Climate change and } \\
\text { insecurity mapping } \\
\text { vulnerability in Africa }\end{array}$ & International Security & Africa & Quantitative & Not applicable \\
\hline Freeman (2017) & $\begin{array}{l}\text { Environmental change, } \\
\text { migration, and conflict } \\
\text { in Africa: A critical } \\
\text { examination of the } \\
\text { interconnections }\end{array}$ & $\begin{array}{l}\text { Journal of } \\
\text { Environment \&t } \\
\text { Development }\end{array}$ & Africa & Qualitative & $\begin{array}{l}\text { Migration and mobility } \\
\text { patterns }\end{array}$ \\
\hline Igwe (2020) & $\begin{array}{l}\text { Climate variation-induced } \\
\text { migration, land conflicts, } \\
\text { and security situation in } \\
\text { Nigeria }\end{array}$ & $\begin{array}{l}\text { Age of Human Rights } \\
\text { Journal }\end{array}$ & Nigeria & Qualitative & $\begin{array}{l}\text { Migration and mobility } \\
\text { patterns }\end{array}$ \\
\hline $\begin{array}{l}\text { Kamta, Schilling } \\
\text { and Scheffran } \\
(2020)\end{array}$ & $\begin{array}{l}\text { Insecurity, resource } \\
\text { scarcity, and migration } \\
\text { to camps of internally } \\
\text { displaced persons in } \\
\text { northeast Nigeria }\end{array}$ & Sustainability & Nigeria & Mixed & $\begin{array}{l}\text { Migration and mobility } \\
\text { patterns }\end{array}$ \\
\hline $\begin{array}{l}\text { Landis, Rezaee- } \\
\text { daryakenari, } \\
\text { Zhang, Thies } \\
\text { and Maciejewski } \\
\text { (2017) }\end{array}$ & $\begin{array}{l}\text { Fording differences? } \\
\text { Conditions mitigating } \\
\text { water insecurity in the } \\
\text { Niger River Basin }\end{array}$ & Political Geography & $\begin{array}{l}\text { Niger River } \\
\text { Basin }\end{array}$ & Quantitative & $\begin{array}{l}\text { Armed group tactical } \\
\text { considerations }\end{array}$ \\
\hline $\begin{array}{l}\text { Lenshie, } \\
\text { Okengwu, } \\
\text { Ogbonna and } \\
\text { Ezeibe (2020) }\end{array}$ & $\begin{array}{l}\text { Desertification, migration, } \\
\text { and herder-farmer conflicts } \\
\text { in Nigeria: Rethinking the } \\
\text { ungoverned spaces thesis }\end{array}$ & $\begin{array}{l}\text { Small Wars } \mathcal{E} \\
\text { Insurgencies }\end{array}$ & Nigeria & Qualitative & $\begin{array}{l}\text { Migration and } \\
\text { mobility patterns; elite } \\
\text { exploitation }\end{array}$ \\
\hline $\begin{array}{l}\text { Madu and } \\
\text { Nwankwo (2020) }\end{array}$ & $\begin{array}{l}\text { Spatial pattern of climate } \\
\text { change and farmer-herder } \\
\text { conflict vulnerabilities in } \\
\text { Nigeria }\end{array}$ & GeoJournal & Nigeria & Quantitative & $\begin{array}{l}\text { Migration and mobility } \\
\text { patterns }\end{array}$ \\
\hline $\begin{array}{l}\text { Nagabhatla and } \\
\text { Brahmbhatt } \\
\text { (2020) }\end{array}$ & $\begin{array}{l}\text { Geospatial assessment } \\
\text { of water-migration } \\
\text { scenarios in the context of } \\
\text { Sustainable Development } \\
\text { Goals (SDGs) 6, 11, and } 16\end{array}$ & Remote Sensing & $\begin{array}{l}\text { Lake Chad, } \\
\text { Nile Delta, } \\
\text { Aral Sea }\end{array}$ & Quantitative & $\begin{array}{l}\text { Migration and mobility } \\
\text { patterns }\end{array}$ \\
\hline
\end{tabular}




\begin{tabular}{|c|c|c|c|c|c|}
\hline Authors & Title & Publication & Area examined & Method & Pathway \\
\hline $\begin{array}{l}\text { Nagabhatla, } \\
\text { Cassidy- } \\
\text { Neumiller, } \\
\text { Francine and } \\
\text { Maatta (2021) }\end{array}$ & $\begin{array}{l}\text { Water, conflicts and } \\
\text { migration and the role of } \\
\text { regional diplomacy: Lake } \\
\text { Chad, Congo Basin, and the } \\
\text { Mbororo pastoralist }\end{array}$ & $\begin{array}{l}\text { Environmental Science } \\
\text { \& Policy }\end{array}$ & $\begin{array}{l}\text { Lake Chad and } \\
\text { Congo Basins }\end{array}$ & Qualitative & $\begin{array}{l}\text { Migration and mobility } \\
\text { patterns }\end{array}$ \\
\hline $\begin{array}{l}\text { Nébié, West and } \\
\text { Crane (2020) }\end{array}$ & $\begin{array}{l}\text { 'Where's the map?': } \\
\text { Integrating ethnography } \\
\text { with maps to understand } \\
\text { the complementarity } \\
\text { between pastoral mobility } \\
\text { and border formation }\end{array}$ & $\begin{array}{l}\text { Journal of Political } \\
\text { Ecology }\end{array}$ & Burkina Faso & Mixed & $\begin{array}{l}\text { Worsening livelihood } \\
\text { conditions; elite } \\
\text { exploitation }\end{array}$ \\
\hline $\begin{array}{l}\text { Okoli and Ogayi } \\
\text { (2018) }\end{array}$ & $\begin{array}{l}\text { Herdsmen militancy } \\
\text { and humanitarian crisis } \\
\text { in Nigeria: a theoretical } \\
\text { briefing }\end{array}$ & $\begin{array}{l}\text { African Security } \\
\text { Review }\end{array}$ & Nigeria & Qualitative & $\begin{array}{l}\text { Worsening livelihood } \\
\text { conditions; migration } \\
\text { and mobility patterns; } \\
\text { armed group tactical } \\
\text { consideration; elite } \\
\text { exploitation }\end{array}$ \\
\hline $\begin{array}{l}\text { Okpara, Stringer } \\
\text { and Dougill (2017) }\end{array}$ & $\begin{array}{l}\text { Using a novel climate-water } \\
\text { conflict vulnerability } \\
\text { index to capture double } \\
\text { exposures in Lake Chad }\end{array}$ & $\begin{array}{l}\text { Regional } \\
\text { Environmental Change }\end{array}$ & $\begin{array}{l}\text { Lake Chad, } \\
\text { Chad }\end{array}$ & Mixed & $\begin{array}{l}\text { Worsening livelihood } \\
\text { conditions }\end{array}$ \\
\hline $\begin{array}{l}\text { Okpara, Stringer } \\
\text { and Dougill (2016) }\end{array}$ & $\begin{array}{l}\text { Lake drying and livelihood } \\
\text { dynamics in Lake } \\
\text { Chad: Unravelling the } \\
\text { mechanisms, contexts and } \\
\text { responses }\end{array}$ & Ambio & $\begin{array}{l}\text { Lake Chad, } \\
\text { Chad }\end{array}$ & Mixed & $\begin{array}{l}\text { Worsening livelihood } \\
\text { conditions }\end{array}$ \\
\hline $\begin{array}{l}\text { Okpara, Stringer, } \\
\text { Dougill and Bila } \\
(2015)\end{array}$ & $\begin{array}{l}\text { Conflicts about } \\
\text { water in Lake Chad: } \\
\text { are environmental, } \\
\text { vulnerability and security } \\
\text { issues linked? }\end{array}$ & $\begin{array}{l}\text { Progress in } \\
\text { Development Studies }\end{array}$ & Lake Chad & Qualitative & $\begin{array}{l}\text { Worsening livelihood } \\
\text { conditions }\end{array}$ \\
\hline $\begin{array}{l}\text { Olaniyan and } \\
\text { Okeke-Uzodike } \\
\text { (2015) }\end{array}$ & $\begin{array}{l}\text { Desperate guests, unwilling } \\
\text { hosts: climate change- } \\
\text { induced migration and } \\
\text { farmer-herder conflicts in } \\
\text { southwestern Nigeria }\end{array}$ & $\begin{array}{l}\text { Conflict Studies } \\
\text { Quarterly }\end{array}$ & Nigeria & Qualitative & $\begin{array}{l}\text { Migration and mobility } \\
\text { patterns }\end{array}$ \\
\hline $\begin{array}{l}\text { Olaniyan, Francis } \\
\text { and Okeke- } \\
\text { Uzodike (2015) }\end{array}$ & $\begin{array}{l}\text { The cattle are 'Ghanaians' } \\
\text { but the herders are } \\
\text { strangers: farmer-herder } \\
\text { conflicts, expulsion policy, } \\
\text { and pastoralist question in } \\
\text { Agogo, Ghana }\end{array}$ & $\begin{array}{l}\text { African Studies } \\
\text { Quarterly }\end{array}$ & Ghana & Qualitative & $\begin{array}{l}\text { Migration and } \\
\text { mobility patterns; elite } \\
\text { exploitation }\end{array}$ \\
\hline $\begin{array}{l}\text { Owonikoko and } \\
\text { Momodu (2020) }\end{array}$ & $\begin{array}{l}\text { Environmental } \\
\text { degradation, livelihood, } \\
\text { and the stability of Chad } \\
\text { Basin Region }\end{array}$ & $\begin{array}{l}\text { Small Wars \& } \\
\text { Insurgencies }\end{array}$ & Lake Chad & Qualitative & $\begin{array}{l}\text { Worsening livelihood } \\
\text { conditions; migration } \\
\text { and mobility patterns; } \\
\text { armed group tactical } \\
\text { considerations; elite } \\
\text { exploitation }\end{array}$ \\
\hline $\begin{array}{l}\text { Papaioannou } \\
(2016)\end{array}$ & $\begin{array}{l}\text { Climate shocks and } \\
\text { conflict: Evidence from } \\
\text { colonial Nigeria }\end{array}$ & Political Geography & Nigeria & Mixed & $\begin{array}{l}\text { Worsening livelihood } \\
\text { conditions }\end{array}$ \\
\hline
\end{tabular}




\begin{tabular}{|c|c|c|c|c|c|}
\hline Authors & Title & Publication & Area examined & Method & Pathway \\
\hline Robert (2010) & $\begin{array}{l}\text { Les zones pastorales } \\
\text { comme solution aux conflits } \\
\text { agriculteurs / pasteurs au } \\
\text { Burkina Faso : l'exemple } \\
\text { de la zone pastorale de la } \\
\text { Doubégué ['Pastoral zones } \\
\text { as a solution to farmer / } \\
\text { pastoralist conflicts in } \\
\text { Burkina Faso: the example } \\
\text { of the pastoral zone of } \\
\text { Doubégué'] }\end{array}$ & $\begin{array}{l}\text { Les Cahiers d'Outre- } \\
\text { Mer }\end{array}$ & Burkina Faso & Qualitative & $\begin{array}{l}\text { Worsening livelihood } \\
\text { conditions; migration } \\
\text { and mobility patterns }\end{array}$ \\
\hline $\begin{array}{l}\text { Seter, Theisen \& } \\
\text { Schilling (2018) }\end{array}$ & $\begin{array}{l}\text { All about water and land? } \\
\text { Resource-related conflicts } \\
\text { in East and West Africa } \\
\text { revisited }\end{array}$ & GeoJournal & $\begin{array}{l}\text { Western Sahel } \\
\text { and East Africa }\end{array}$ & Qualitative & Elite exploitation \\
\hline $\begin{array}{l}\text { Snorek, Moser and } \\
\text { Renaud (2017) }\end{array}$ & $\begin{array}{l}\text { The production of } \\
\text { contested landscapes: } \\
\text { enclosing the pastoral } \\
\text { commons in Niger }\end{array}$ & $\begin{array}{l}\text { Journal of Rural } \\
\text { Studies }\end{array}$ & Niger & Qualitative & Elite exploitation \\
\hline $\begin{array}{l}\text { Snorek, Renaud } \\
\text { and Kloos (2014) }\end{array}$ & $\begin{array}{l}\text { Divergent adaptation } \\
\text { to climate variability: A } \\
\text { case study of pastoral and } \\
\text { agricultural societies in } \\
\text { Niger }\end{array}$ & $\begin{array}{l}\text { Global Environmental } \\
\text { Change }\end{array}$ & Niger & Qualitative & $\begin{array}{l}\text { Worsening livelihood } \\
\text { conditions; migration } \\
\text { and mobility patterns; } \\
\text { elite exploitation }\end{array}$ \\
\hline $\begin{array}{l}\text { Thébaud and } \\
\text { Batterbury (2001) }\end{array}$ & $\begin{array}{l}\text { Sahel pastoralists: } \\
\text { opportunism, struggle, } \\
\text { conflict and negotiation. } \\
\text { A case study from eastern } \\
\text { Niger }\end{array}$ & $\begin{array}{l}\text { Global Environmental } \\
\text { Change }\end{array}$ & Niger & Qualitative & $\begin{array}{l}\text { Worsening livelihood } \\
\text { conditions; elite } \\
\text { exploitation }\end{array}$ \\
\hline $\begin{array}{l}\text { Traore and Owiyo } \\
\text { (2013) }\end{array}$ & $\begin{array}{l}\text { Dirty droughts causing loss } \\
\text { and damage in Northern } \\
\text { Burkina Faso }\end{array}$ & $\begin{array}{l}\text { International Journal } \\
\text { of Global Warming }\end{array}$ & Burkina Faso & Qualitative & $\begin{array}{l}\text { Worsening livelihood } \\
\text { conditions; migration } \\
\text { and mobility patterns }\end{array}$ \\
\hline Varin (2020) & $\begin{array}{l}\text { No opportunity lost: The } \\
\text { ISWAP insurgency in the } \\
\text { changing climate of Lake } \\
\text { Chad Region }\end{array}$ & $\begin{array}{l}\text { African Conflict and } \\
\text { Peacebuilding Review }\end{array}$ & Lake Chad & Qualitative & $\begin{array}{l}\text { Armed group tactical } \\
\text { considerations; elite } \\
\text { exploitation }\end{array}$ \\
\hline Walch (2018) & $\begin{array}{l}\text { Disaster risk reduction } \\
\text { amidst armed conflict: } \\
\text { informal institutions, } \\
\text { rebel groups, and wartime } \\
\text { political orders }\end{array}$ & Disasters & $\begin{array}{l}\text { Mali and the } \\
\text { Philippines }\end{array}$ & Qualitative & $\begin{array}{l}\text { Armed group tactical } \\
\text { considerations }\end{array}$ \\
\hline
\end{tabular}

Source: Author's compilation. 


\section{RECENT SIPRI PUBLICATIONS}

Multidomain Deterrence and Strategic Stability in China

Dr Lora Saalman

SIPRI Insights on Peace and Security

January 2022

Pathways for Reducing Military Spending in Post-civil Conflict Settings Dr Diego Lopes da Silva, Dr Nan Tian and Alexandra Marksteiner SIPRI Insights on Peace and Security January 2022

\section{Food Systems in Conflict and Peacebuilding Settings: Ways Forward} Dr Kristina Tschunkert and Dr Caroline Delgado SIPRI Report January 2022

Peace Operations and the Challenges of Environmental Degradation and Resource Scarcity

Oli Brown

SIPRI Background Paper

December 2021

Taking Stock of the Arms Trade Treaty: Achievements, Challenges and Ways Forward

Dr Andrea Edoardo Varisco, Giovanna Maletta and Lucile Robin

SIPRI Report

December 2021

Taking Stock of the Arms Trade Treaty: A Summary of Policy Options Dr Andrea Edoardo Varisco, Giovanna Maletta and Lucile Robin SIPRI Policy Brief

December 2021

\section{Reform within the System: Governance in Iraq and Lebanon} Amal Bourhrous, Shivan Fazil, Meray Maddah and Dr Dylan O’Driscoll SIPRI Policy Paper

December 2021

Fixing the Economy and Public Service Provision in Lebanon Amal Bourhrous SIPRI Policy Brief December 2021

Fixing the Economy and Public Service Provision in Iraq Shivan Fazil SIPRI Policy Brief

December 2021 


\section{RELATED SIPRI PUBLICATIONS}

Water Cooperation in the Horn of Africa: Addressing Drivers of Conflict and Strengthening Resilience

Dr Kyungmee Kim, Emilie Broek,Elizabeth S. Smith, David Michel, Erwin De Nys and Nicolas Salazar Godoy

SIPRI-CIWA report

December 2021

Advancing the Role of the OSCE in the Field of Climate Security

Niklas Bremberg and Anniek Barnhoorn

SIPRI Policy Brief

September 2021

Anthropocene (In)securities: Reflections on Collective Survival 50

Years After the Stockholm Conference

Dr Malin Mobjörk and Eva Lövbrand

SIPRI Research Report

September 2021

Climate-related Security Risks and Peacebuilding in Mali

Dr Farah Hegazi, Dr Florian Krampe and Elizabeth Smith

SIPRI Policy Paper

April 2021

Climate-related Security Risks and the African Union

Vane Moraa Aminga and Dr Florian Krampe

SIPRI Policy Brief

May 2020

Policy Responses to Climate-related Security Risks: The African Union

Vane Moraa Aminga

SIPRI Policy Paper

March 2020

Water Security and Governance in the Horn of Africa

Dan Smith, Dr Florian Krampe, Luc van de Goor, Anniek Barnhoorn

and Elizabeth Smith

SIPRI Policy Paper

March 2020

Climate-related Security Risks and Peacebuilding in Somalia

Karolina Eklöw and Dr Florian Krampe

SIPRI Policy Paper

October 2019

Advancing United Nations Responses to Climate-related Security Risks

Camilla Born, Karolina Eklöw and Dr Malin Mobjörk

SIPRI Policy Brief

September 2019 
SIPRI is an independent international institute dedicated to research into conflict, armaments, arms control and disarmament. Established in 1966, SIPRI provides data, analysis and recommendations, based on open sources, to policymakers, researchers, media and the interested public.

\section{GOVERNING BOARD}

Ambassador Jan Eliasson, Chair (Sweden)

Ambassador Chan Heng Chee

(Singapore)

Jean-Marie Guéhenno (France)

Dr Radha Kumar (India)

Dr Patricia Lewis (Ireland/

United Kingdom)

Dr Jessica Tuchman Mathews

(United States)

Dr Feodor Voitolovsky (Russia)

\section{DIRECTOR}

Dan Smith (United Kingdom)

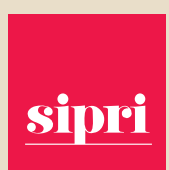

STOCKHOLM INTERNATIONAL PEACE RESEARCH INSTITUTE

Signalistgatan 9

SE-169 72 Solna, Sweden

Telephone: +4686559700

Email:sipri@sipri.org

Internet: www.sipri.org
SIPRI INSIGHTS ON PEACE AND SECURITY NO. 2022/3

\section{CLIMATE CHANGE AND VIOLENT CONFLICT IN WEST AFRICA: ASSESSING THE EVIDENCE}

KHEIRA TARIF

\section{CONTENTS}

I. Introduction

Figure 1. Map of United Nations Office for West Africa and the Sahel 2 (UNOWAS) member states with ND-GAIN Country Index scores

II. Climate change, vulnerability and insecurity in West Africa 3

Climate change in West Africa

Climate vulnerability and governance 3

Insecurity and humanitarian crises $\quad 4$

III. Pathways of climate insecurity 5

Worsening livelihood conditions 6

Increasing migration and changing pastoral mobility patterns 8

Tactical considerations by armed groups $\quad 12$

Elite exploitation of local grievances $\quad 14$

IV. Implications for research and policymaking $\quad 16$

$\begin{array}{ll}\text { Livelihood resilience and climate adaptation } & 17\end{array}$

$\begin{array}{ll}\text { The dynamics of changing migration patterns and changing risks } & 17\end{array}$

$\begin{array}{ll}\text { Local governance mechanisms } & 17\end{array}$

Annex A. Methodology 18

Table A.1. Full details of the literature sample $\quad 19$

\section{ABOUT THE AUTHOR}

Kheira Tarif (Algeria/United Kingdom) is a Research Assistant in the Climate Change and Risk Programme at SIPRI. Her research focuses on the pathways between climate change and violent conflict. 